\title{
State of the art of the Fontan strategy for treatment of
}

\section{univentricular heart disease [version 1; peer review: 2}

\section{approved]}

\author{
Jelle P. G. van der Ven (D1,2, Eva van den Bosch1,2, Ad J.C.C. Bogers33, \\ Willem A. Helbing 1 \\ ${ }^{1}$ Department of Pediatrics, Division of Pediatric Cardiology, Erasmus MC-Sophia Children's Hospital, Rotterdam, The Netherlands \\ ${ }^{2}$ Netherlands Heart Institute, Utrecht, The Netherlands \\ ${ }^{3}$ Department of Cardiothoracic Surgery, Erasmus MC, Rotterdam, The Netherlands
}

V1 First published: 27 Jun 2018, 7(F1000 Faculty Rev):935

https://doi.org/10.12688/f1000research.13792.1

Latest published: 27 Jun 2018, 7(F1000 Faculty Rev):935

https://doi.org/10.12688/f1000research.13792.1

\section{Open Peer Review}

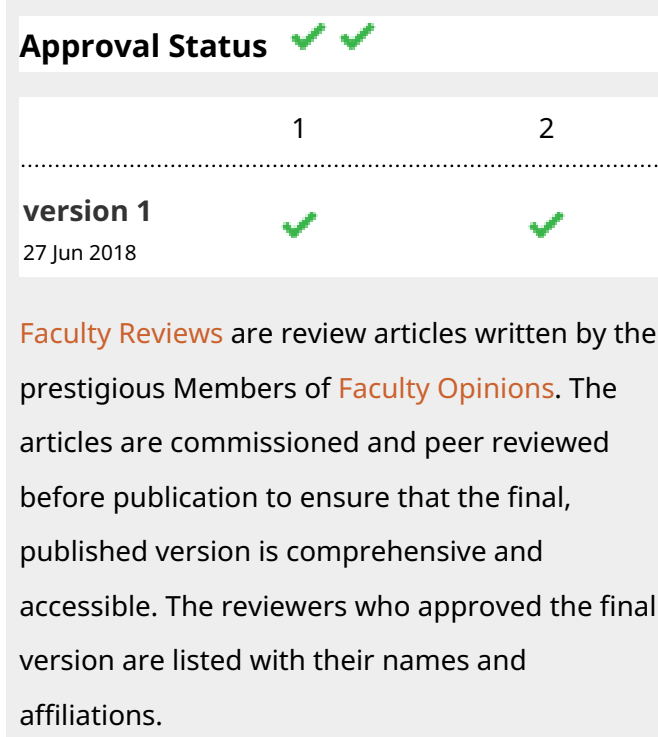

1. Gruschen R. Veldtman, Cincinnati Children's Hospital Medical Centre, Cincinnati, USA

2. Amy Throckmorton, Drexel University, Philadelphia, USA

Any comments on the article can be found at the end of the article.
Fontan Procedure, Total cavopulmonary connection, Congenital heart defects, Single ventricle, Pediatrics, Mortality, Morbidity, Reinterventions 
Corresponding author: Willem A. Helbing (w.a.helbing@erasmusmc.nl)

Author roles: van der Ven JPG: Investigation, Writing - Original Draft Preparation; van den Bosch E: Investigation, Writing - Review \& Editing; Bogers AJCC: Writing - Review \& Editing; Helbing WA: Conceptualization, Supervision, Writing - Review \& Editing

Competing interests: No competing interests were disclosed.

Grant information: The author(s) declared that no grants were involved in supporting this work.

Copyright: () 2018 van der Ven JPG et al. This is an open access article distributed under the terms of the Creative Commons Attribution License, which permits unrestricted use, distribution, and reproduction in any medium, provided the original work is properly cited.

How to cite this article: van der Ven JPG, van den Bosch E, Bogers AJCC and Helbing WA. State of the art of the Fontan strategy for treatment of univentricular heart disease [version 1; peer review: 2 approved] F1000Research 2018, 7(F1000 Faculty Rev):935 https://doi.org/10.12688/f1000research.13792.1

First published: 27 Jun 2018, 7(F1000 Faculty Rev):935 https://doi.org/10.12688/f1000research.13792.1 


\section{Introduction}

Functionally univentricular congenital heart disease (CHD), in which only one ventricle is fully developed, poses a complex clinical problem. Estimates of the incidence of this disease entity range from 0.08 to 0.4 per 1,000 births ${ }^{1-3}$. Functionally univentricular CHD entails different morphological diagnoses, the most common of which are hypoplastic left heart syndrome (HLHS) (25 to 67\% of functionally univentricular hearts), tricuspid atresia (15 to 24\%), and double inlet left ventricle $(14 \text { to } 18 \%)^{1,3-5}$. It is estimated that currently there are about 22,000 patients in Europe and about 50,000 in the US ${ }^{6}$. Recent advancements in prenatal screening have increased the rates of prenatal diagnosis and possibly termination of pregnancy in patients with univentricular hearts ${ }^{1,7}$. Despite the low incidence, improvements in treatment have reduced the mortality to the point where a large number of patients survive into adulthood.

Palliation can be achieved with the Fontan strategy. A series of operations is performed to palliate the adverse effects of a univentricular heart. The Fontan strategy refers to the landmark surgery for tricuspid atresia by Fontan and Baudet ${ }^{8}$. In the "early days" of this procedure, it was attempted to replace the function of the right ventricle with the right atrium by connecting the right atrium to the pulmonary artery. Although short-term results were unprecedented, this strategy caused dilation of the right atrium, resulting in arrhythmia and thromboembolism due to sluggish blood flow ${ }^{9}$. Modifications of this surgery are referred to as atriopulmonary connections (APCs). In a later era, de Leval et al. found that atrial contractions did not contribute significant power to the APC circuit and proposed the intra-atrial lateral tunnel (ILT), a transatrial connection using an intra-atrial baffle connecting the inferior caval vein to the pulmonary artery in a more energetically favorable manner ${ }^{10}$. Currently, most centers employ an extracardiac conduit (ECC), a prosthetic conduit that bypasses the atrium completely. Both ILT and ECC are referred to as total cavopulmonary connection (TCPC) Fontan modifications.

A Fontan circuit was originally created in a single surgical setting. This resulted in relatively high mortality. A staged TCPC, in which a series of operations is performed at different ages, is the current standard of care. These operations are tailored to the individual anatomy of the patient. First, the single ventricle (SV) needs to be connected to the aorta, which may require extensive surgery, such as the Norwood procedure for HLHS. At about 3 to 6 months of age, a partial cavopulmonary connection (PCPC), connecting the superior caval vein to the pulmonary artery (that is, bidirectional Glenn procedure), is performed. Completion of the TCPC is usually performed between 18 months and 4 years of age ${ }^{4}$. The connections and circulatory pattern after these operations are illustrated in Figure 1.

These patients require a lifetime of highly specialized care and significant health-care resources. In Oceania, the mean hospital

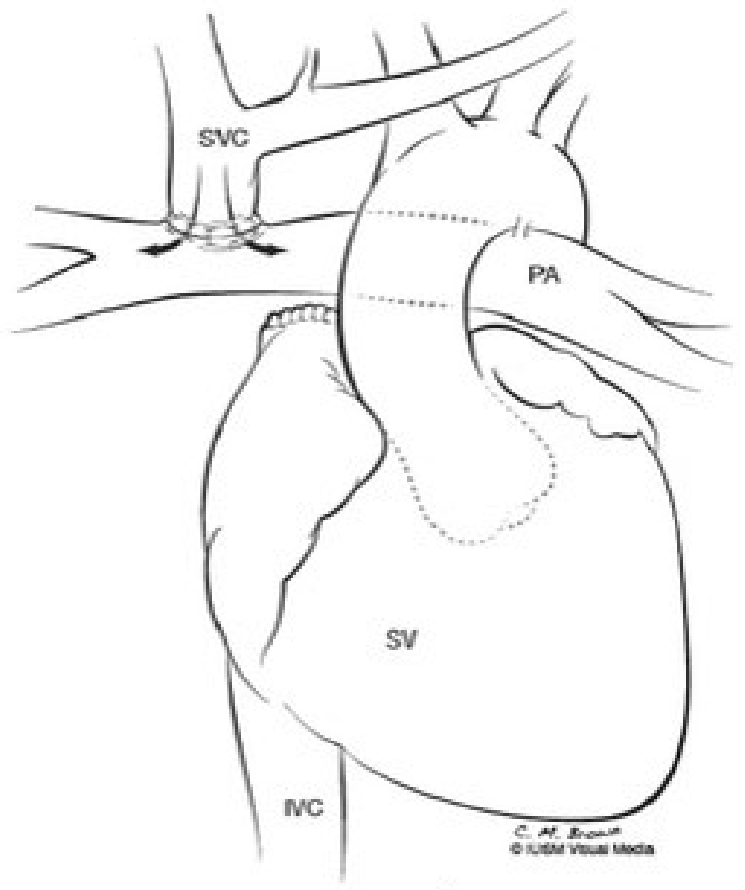

A

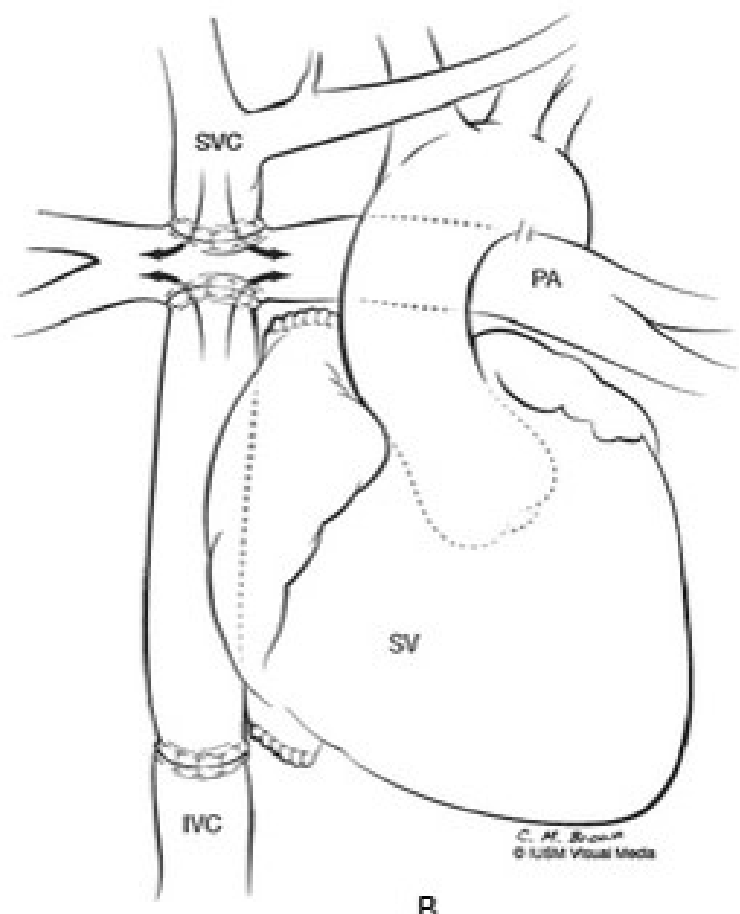

B

Figure 1. Illustration of the anatomic relationships following partial cavopulmonary connection (A) and total cavopulmonary connection (B) palliation. IVC, inferior vena cava; PA, pulmonary artery; SV, single ventricle; SVC, superior vena cava. This figure has been reproduced with permission from Kerlo et al. and Springer Nature ${ }^{11}$. 
costs across all stages of palliation are about $\$ 200,000$ per patient $^{12}$. Following Fontan palliation, hospital admission rates for patients are eight times higher than for the general population $^{13}$, and both length of stay and hospital costs are higher compared with those of other CHDs, including tetralogy of Fallot $^{14-16}$.

\section{Physiology}

In unpalliated univentricular $\mathrm{CHD}$, cyanosis occurs because of mixing of saturated and unsaturated blood in the heart. The SV is also exposed to volume overload as it drains both systemic and pulmonary venous return at the same time. The Fontan strategy reduces volume overload and restores normoxemia. Following PCPC surgery, some volume unloading of the $\mathrm{SV}$ is achieved. Following TCPC, the volume load of the SV is further reduced ${ }^{17}$. Furthermore, after TCPC, the systemic and pulmonary blood flows are connected in series rather than parallel as before this strategy has been deployed. This comes at the expense of the lack of a ventricle supplying energy to the pulmonary circulation. This is illustrated in Figure 2. The SV provides the energy needed to attain blood flow through the systemic as well as the pulmonary vascular bed and is subjected to increased afterload. After TCPC, central venous pressures are higher than normal. Pulsatility in the pulmonary artery is mostly lost and there is preload insufficiency of the SV. This highly abnormal circulation is called the Fontan circulation. The resulting physiology has been referred to as a "Fontan paradox", where systemic venous pressure is high in the presence of relative pulmonary artery hypotension ${ }^{18}$. This might augment lymphatic outflow and impede lymphatic inflow from the thoracic duct. Several complications of the Fontan strategy have been linked to abnormalities in lymphatic drainage. Because of the multiple inherent hemodynamic challenges of the Fontan circulation, it is generally considered a palliative procedure $^{19}$.

The aim of this article is to provide an overview of current outcomes, treatment options, and remaining challenges to improve outlook for patients with univentricular heart disease.

\section{State of the art}

\section{Overall survival}

Survival following the Fontan procedure has increased dramatically in the past few decades. We will discuss data from
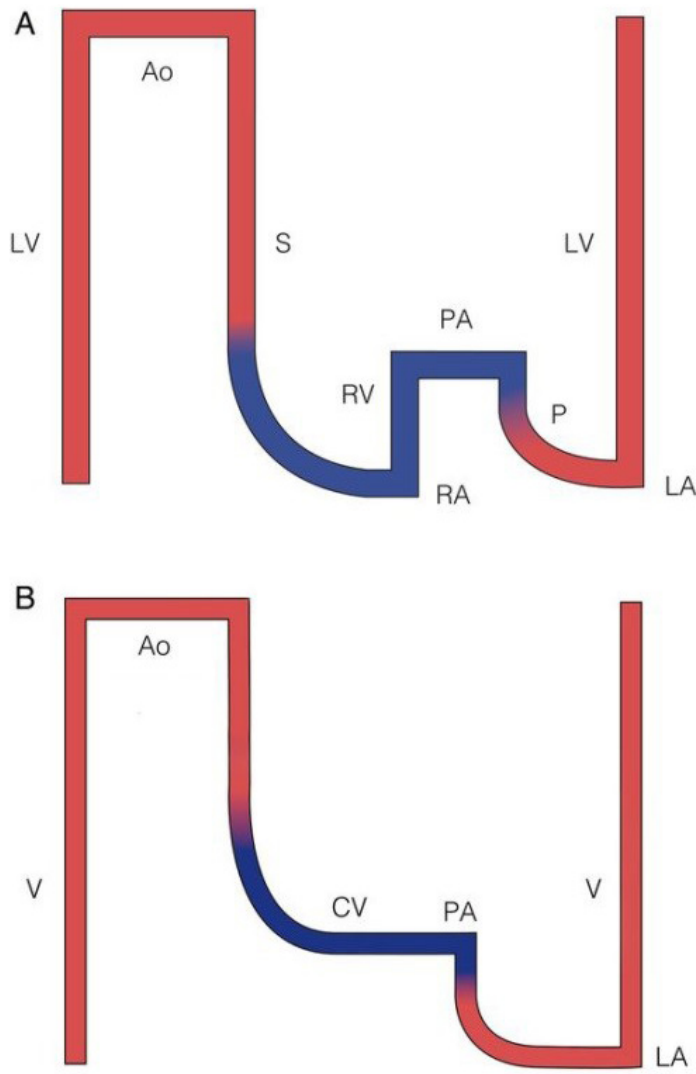

Figure 2. Scheme of pressures in the normal circulation $(\mathbf{A})$ and the Fontan circulation (B). This scheme illustrates the effects of the lack of a prepulmonary pump in the Fontan physiology. Red represents oxygenated blood and blue represents deoxygenated blood. Ao, aorta; CV, caval veins; LA, left atrium; LV, left ventricle; P, pulmonary circulation; PA, pulmonary artery; RA, right atrium; RV, right ventricle; S, systemic circulation; $\mathrm{V}$, single ventricle. This figure has been reproduced with permission from Gewillig and Brown and the British Medical Journal Publishing Group Ltd ${ }^{20}$. 
recently published reports of large cohorts with long follow-up intervals. An overview of studies assessing survival is presented in Figure 3, obtained from Kverneland et al. ${ }^{21}$.

In a recent study from Oceania, perioperative mortality decreased from $8 \%$ between 1975 and 1990 to $1 \%$ in 2001-201022. In this cohort, early Fontan takedown occurred in $2 \%$ of patients. Ten-year survival among patients discharged with a Fontan circulation was $89 \%$ following APC and $97 \%$ for both ECC and ILT $^{23}$. Survival at 25 years was $76 \%$. This group was composed only of APC patients.

In a retrospective study from the Mayo Clinic of 40 years and 1,052 Fontan patients, overall survival rates were $74 \%$ at 10 years, $61 \%$ at 20 years, and $43 \%$ at 30 years $^{24}$. Survival was significantly higher in later surgical eras, and 10-year survival was 95\% for patients operated on after 2001. Interestingly, patients operated on with the ECC technique showed better overall survival over ILT. It should be taken into account that patients with cardiac defects with worse prognosis were more frequently operated on using the ILT technique.

A Danish national registry described outcomes for SV patients from 1977 to 2009'. Fifty percent of patients died before Fontan completion. Overall survival improved in later birth eras. Five-year survival for any univentricular CHD increased from $22 \%$ in $1977-1989$ to $51 \%$ in $2000-2009$.

One should note that follow-up studies after Fontan procedures reflect results of an earlier surgical era and do not necessarily represent the outlook of Fontan patients undergoing surgery in the current era.

\section{Determinants of survival}

Several factors have been associated with survival after the Fontan procedure. Of preoperative factors, male gender ${ }^{23}$ and specific CHD diagnosis, most strikingly for $\mathrm{HLHS}^{25}$, have been associated with worse long-term survival. Perioperative risk factors for mortality include APC type procedure, earlier surgical era, older age at procedure, concomitant valve replacement, and prolonged postoperative pleural effusion ${ }^{25}$. Postoperative factors that affect survival include elevated central venous pressure and lower arterial saturation ${ }^{26}$; imaging-derived parameters such as lower global longitudinal strain on echocardiography and higher end-diastolic volume measured by magnetic resonance imaging (MRI) ${ }^{25}$; peak heart rate and peak oxygen uptake during cardiopulmonary exercise testing ${ }^{25,27,28}$; and serum levels of sodium, creatinine, and brain natriuretic peptide ${ }^{25,29,30}$.

\section{Cardiac complications}

Although survival following Fontan completion has increased over time, the Fontan strategy has been associated with important morbidity, most likely related to extensive surgical procedures and the highly abnormal circulatory state after these procedures. In recent cohorts, event-free survival has ranged from 59 to $81 \%$ at 15 years $^{23,31}$.

The most commonly reported event is cardiac arrhythmia. Supraventricular tachycardia (SVT) contributes significantly to

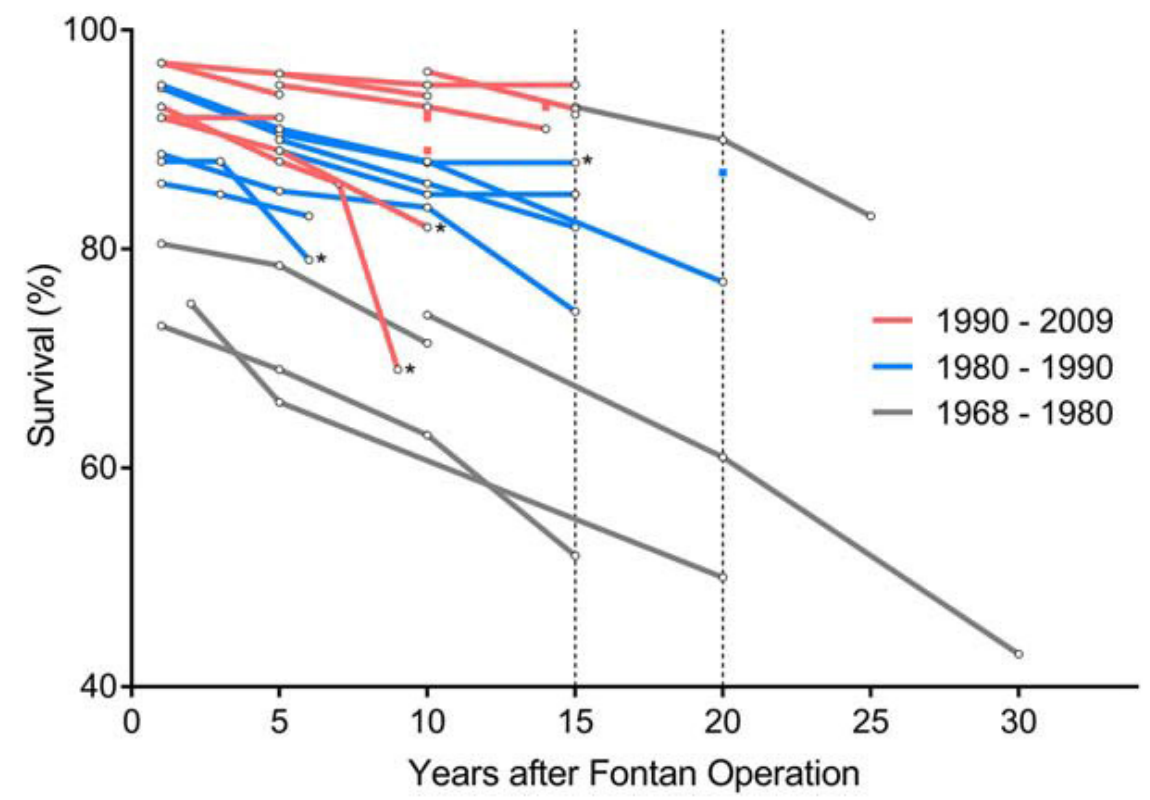

Figure 3. Survival following Fontan completion. Each line represents a study assessing survival at multiple time points and is colored by surgical era. Dots represent Kaplan-Meier survival estimates. Studies marked with an asterisk show survival curves for death, transplant, or Fontan revision; others show survival curves for only death. This figure has been reproduced with permission from Kverneland et al. and John Wiley and Sons ${ }^{21}$. 
late mortality in Fontan patients ${ }^{32}$. SVT has been associated with Fontan type; the highest risk is for APC type, followed by ILT, and the lowest is for $\mathrm{ECC}^{23,33}$. Results may have improved for the ILT technique after introduction of the prosthetic modification $^{35}$. The incidence of SVT increases during follow-up, and after 20 years of follow-up, 10 to $60 \%$ of patients have experienced some form of SVT ${ }^{34,35}$.

Failure of the Fontan circulation can occur even in long-standing uncomplicated Fontan circulations. The definition of Fontan failure varies but generally includes excessive constitutional limitations of the Fontan physiology, abnormal parameters of hemodynamic function, poor functional status, or the presence of Fontan sequelae ${ }^{36}$. Fontan failure occurs in 2 to $13 \%$ of patients, depending on definitions and follow-up period ${ }^{36}$. A $56 \%$ 25-year freedom of Fontan failure for APC connections has been reported $^{23}$.

\section{Extracardiac complications}

Abnormalities of coagulation. Blood flow can be slow in the Fontan circuit because of the absence of a prepulmonary pump. This promotes coagulation. Furthermore, coagulation factor abnormalities have been described in the SV patient, even before PCPC palliation ${ }^{37}$. Thromboembolic events are more common following APC surgery than $\mathrm{TCPC}^{37}$. The prevalence of thrombi is particularly high in those who develop atrial arrhythmias ${ }^{38}$. Up to $65 \%$ of thrombi are detected within the first year following TCPC (early thromboembolic events) ${ }^{39}$. Early thromboembolic events probably relate to perioperative factors, such as extracorporeal membrane oxygenation (ECMO) use and altered hemodynamics. Beyond 10 years after Fontan completion, incidence of late thromboembolism steadily increases ${ }^{39}$. Reports of the incidence of thromboembolism are complicated by different definitions and methods of detection. Studies report incidences of late thromboembolism of between 1 and $25 \%{ }^{31,40}$. Silent thrombi are detected with transesophageal echocardiography in up to $33 \%$ of patients ${ }^{41}$. Thromboembolic events have been reported to account for $8 \%$ of Fontan deaths ${ }^{42}$.

Liver function abnormalities, cirrhosis, and even hepatocellular carcinoma have been reported following Fontan surgery ${ }^{43}$. The elevated systemic venous pressures encountered in the Fontan circulation lead to chronic venous congestion in the liver. However, the exact mechanism for Fontan-associated liver disease remains unknown, as does how best to monitor progression ${ }^{44,45}$. The American College of Cardiology recently provided a position statement on the subject, advising laboratory and imaging screening at least every 3-5 years in children and at least every 1-3 years in adult Fontan patients ${ }^{46}$. Preventive strategies need to be developed.

Protein-losing enteropathy (PLE) is a devastating complication of the Fontan circulation in which loss of protein in the gastrointestinal tract occurs, leading to low albumin levels, edema, pleural effusions, and ascites. Incidences of between 3 and $29 \%$ have been reported ${ }^{24,31,35,47}$. It is thought to be caused, in part, by impairments in the lymphatic drainage. Hepatoduodenal lymphatic connections exist in some patients as a normal anatomic variant, which might induce competition in lymphatic flow in the presence of elevated venous pressure, diverting lymphatic flow to the gastrointestinal tract.

Plastic bronchitis is a serious pulmonary complication of the Fontan circulation in which large gelatinous casts are formed in the airways. It is thought to be related to abnormal lymphatic drainage directly into the airways, resulting in cast formation. Reported incidences range from 0.5 to $4 \%{ }^{48-50}$.

Chronic kidney disease is estimated to be present in up to $50 \%$ of adult Fontan patients and is associated with adverse outcomes $^{30,51}$. With the increasing availability of cystatin C-determined glomerular filtration rate (GFR), a muscle massindependent estimate, the prevalence of clinically significant renal dysfunction appears to be lower ${ }^{52}$. GFR estimates based on serum creatinine concentrations probably overestimate renal function in Fontan patients ${ }^{51}$.

Psychological, psychiatric, and cognitive defects have been described in Fontan patients. Cerebral MRI has shown morphological differences in some cerebral structures of Fontan patients compared with those of healthy controls ${ }^{53,54}$. Interestingly, the pituitary gland, supplied by a portal venous system similar to the liver, appears to be enlarged following Fontan surgery ${ }^{55}$. The relevance of this possible congestion on the endocrine system remains unclear.

\section{Re-interventions}

Many patients require additional surgical and catheter-based interventions following Fontan completion. Twenty-year freedom of re-operation following TCPC procedures in recent eras ranges from 86 to $92 \%{ }^{56}$. In older cohorts, higher re-operation rates have been reported ${ }^{24,57,58}$. The most common surgical re-intervention procedures, in order of incidence, are pacemaker implantation in 9 to $23 \%$ of patients ${ }^{23,24}$, Fontan revision or conversion in 3 to $18 \%$ of patients ${ }^{9,24,59}$, and atrioventricular (AV) valve repair in 1 to $14 \%$ of patients $\mathrm{s}^{24,59,60}$.

Fontan conversion, from APC to TCPC, can improve functional status and exercise tolerance in the failing Fontan circulation $^{61}$. AV valve repair after Fontan completion is considered in patients with moderate to severe regurgitation, but survival following successful repair remains inferior to that of patients without prior AV regurgitation ${ }^{62,63}$.

For several reasons, re-interventions by catheter may be required. A fenestration in the atrial tunnel, inducing a rightto-left atrial shunt, can be created during surgery to decrease systemic venous pressure, increase ventricular preload, and improve cardiac output at the cost of lower arterial saturation. This fenestration sometimes closes spontaneously or can be closed via catheter at a later time ${ }^{64}$.

Hemodynamically significant obstruction in the Fontan pathway may occur, most commonly in the left pulmonary artery ${ }^{57,65}$. In the absence of a prepulmonary pump, this can severely affect the Fontan circulation, and obstructions are routinely dilated or stented. 
Systemic to pulmonary venous collaterals can produce a right-to-left shunting which often worsens in time. Coiling of these collaterals is routinely performed in some centers, although no survival benefit has been demonstrated ${ }^{66}$.

Aortopulmonary collaterals are common in the Fontan circulation. They increase pulmonary blood flow but induce a volume overload on the SV and might increase pulmonary artery pressure, limiting flow from the caval veins ${ }^{65}$. During exercise, aortopulmonary flow increases, possibly augmenting loading conditions of the ventricle ${ }^{67}$. A large aortopulmonary collateral burden has been associated with worse short-term outcomes ${ }^{68}$. No clear consensus regarding the long-term effects and management of these collaterals exists ${ }^{65}$.

Catheter ablation of an arrhythmogenic substrate is common. Long-term success rates vary between 15 and $72 \%{ }^{69,70}$.

The reported incidence of catheter-based interventions (that is, excluding diagnostic cardiac catheterization without intervention) varies heavily; 3 to $65 \%$ of patients require at least one additional catheter intervention following Fontan completion $^{31,56,57,59,71}$. The most common catheter interventions are fenestration closure (10 to $64 \%$ of patients with a fenestration require catheter-based fenestration closing ${ }^{56,57,59,72}$, occlusion of veno-venous or aortopulmonary collaterals (incidence of 10 to $20 \%)^{57,59}$, and stenting and dilation of (all types of) obstructions in the Fontan pathway (incidence of 6 to 19\%) ${ }^{57,59,73}$.

\section{Other outcomes and functional status}

Most studies report a diminished quality of life in Fontan patients compared with healthy controls ${ }^{74-78}$. Physical and emotional functioning are the most severely affected domains $^{74,79}$. Low perceived health status can lead to unnecessary restrictions in daily life. Furthermore, increased rates of developmental disorders and lower intelligence scores have been reported in the Fontan population ${ }^{53,76}$.

Fontan patients have a moderately decreased exercise capacity compared with healthy controls ${ }^{80}$. Mean peak oxygen uptake ranges from 61 to $74 \%$ of predicted values ${ }^{80-82}$. A small fraction of Fontan patients have normal exercise capacity ${ }^{83}$. Exercise capacity in the Fontan patient has been shown to decrease over time $^{81,82}$. Exercise capacity is predictive of hospital admissions, quality of life, and late mortality ${ }^{25,28,79,82}$. Exercise training can be done successfully in Fontan patients and can improve quality of life, functional class, and health perception in a short-term follow-up ${ }^{84-87}$. Whether exercise training has a role in optimizing long-term outcome is currently not clear ${ }^{84,86-89}$. Resistance training can be used to increase muscle mass. In the Fontan patient, this could augment peripheral venous return, augment ventricular preload, and improve cardiac output ${ }^{90}$. Similarly, a benefit of inspiratory muscle training has been demonstrated ${ }^{91}$

Despite high morbidity and suboptimal outcomes, most patients with a well-functioning Fontan circulation manage to lead fulfilling lives, are employed, may attain academic achievements, can participate in sports, and are able to successfully carry pregnancy to term ${ }^{92-94}$.

\section{Assessment techniques}

Fontan patients are routinely assessed for health and functional status. Diagnostic cardiac catheterization has been standard practice in the pre-TCPC evaluation, as it provides excellent anatomic and necessary hemodynamic information regarding the pulmonary artery pressure, pulmonary vascular resistance, and end-diastolic SV pressure ${ }^{95}$. There is recent interest in omitting cardiac catheterization in the pre-TCPC assessment for low-risk SV patients ${ }^{95-97}$. No consensus regarding this policy has been reached, as long-term outcomes are currently unavailable. Catheter-based interventions are discussed above.

Cardiac magnetic resonance imaging (CMR) is routinely performed during follow-up after TCPC, particularly to assess ventricular size and function and to quantify large vessel flow, including the amount of collateral flow ${ }^{98-102}$. Death and (being listed for) heart transplantation have been associated with higher end-diastolic volume index $(\mathrm{EDVi})\left(>125 \mathrm{~mL} / \mathrm{m}^{2}\right)$ as assessed with CMR in adolescents with a Fontan circulation ${ }^{103,104}$. Combined with a computational fluid dynamics approach, CMR might provide very useful information on the Fontan circulation and can aid in the evaluation of modifications in treatment strategies ${ }^{104,105}$.

Echocardiographic strain measurements have been shown to predict survival in the Fontan population and predict length of hospital stay following TCPC ${ }^{104,106}$. Assessment of ventriculoarterial (VA) coupling may be another important parameter, as it is independent of the (often impaired) ventricular load. VA coupling has been shown to be suboptimal in some Fontan populations ${ }^{107}$. Currently, VA coupling has not been associated with long-term outcomes in the Fontan population.

Lymphangiography could play an important role in the management of Fontan complications with a suspected lymphatic pathogenesis, such as PLE and plastic bronchitis. In patients with PLE or plastic bronchitis, increased diameters of major lymphatic vessels have been noted ${ }^{108}$. Abnormal lymphatic depositions in the lungs and liver have been visualized in patients with plastic bronchitis and PLE, respectively ${ }^{109,110}$.

\section{Medical therapy}

Anticoagulation, in the form of anti-platelet drugs or vitamin $\mathrm{K}$ antagonists (VKAs), is commonly indicated considering the increased risk for thromboembolic events, as discussed above in the "Extracardiac complications" section"11. A metaanalysis by Alsaied et al. showed that both acetylsalicylic acid and VKA were equally effective in preventing thromboembolic complications ${ }^{112}$. However, if international normalized ratio (INR) is not properly controlled, outcomes on VKA are worse compared with acetylsalicylic acid ${ }^{113}$. Novel oral anticoagulants (NOACs) do not require frequent monitoring and have mostly outperformed VKA in the adult population. Thirty-day outcomes following NOAC initiation show no major 
adverse events in the adult CHD population ${ }^{114}$. However, no NOAC agent currently has US Food and Drug Administration approval for use in children.

\section{Medical prevention of circulatory failure in the Fontan circulation}

Various medications have been assessed in the management of Fontan failure. No studies have shown benefit of angiotensinconverting enzyme (ACE) inhibitor therapy on survival, ventricular function, or cardiopulmonary exercise outcomes ${ }^{115,116}$.

Vasodilator drugs have been used to lower pulmonary vascular resistance $^{117,118}$. Sildenafil has increased ventricular function, exercise capacity, and New York Heart Association (NYHA) status after 6 weeks of follow-up ${ }^{119,120}$. The effects of bosentan, an endothelin antagonist, in the Fontan population have varied $^{121-126}$. No long-term survival benefit of vasodilator therapy has yet been demonstrated ${ }^{119}$.

\section{Mechanical circulatory support for the failing Fontan circulation}

The failing Fontan circulation can be supported by mechanical assist devices. Despite increasing use and the development of novel devices specifically for the pediatric and CHD population, experience in this population is still limited ${ }^{127}$. Mechanical support devices are mostly used as a bridge to transplant in the failing Fontan ${ }^{128}$. Recent reports showed a $60 \%$ 12month survival in 48 Fontan patients with a ventricular assist device, proving viability of longer mechanical circulatory support ${ }^{129,130}$. A total biventricular artificial heart, the SynCardia, has been used to bridge a failing Fontan patient to transplant ${ }^{131}$. A registry of mechanical circulatory support specifically for SV patients has been initiated ${ }^{132}$. Currently, mechanical circulatory support in Fontan patients is associated with worse survival compared with mechanical circulatory support patients with a biventricular circulation ${ }^{133-135}$.

\section{Cardiac transplantation}

Cardiac transplantation is the only treatment that truly corrects Fontan physiology, and it is employed in the failing Fontan circulation. In large cohorts, 1.6 to $3.6 \%$ of patients ultimately underwent cardiac transplant ${ }^{23,24}$. Survival following cardiac transplantation in Fontan patients is generally worse compared with other types of $\mathrm{CHD}^{136,137}$. Five-year survival ranges from 60 to $67 \%^{136-138}$.

\section{Surgical innovations}

Continual efforts are made to improve the surgical techniques used in Fontan surgery. Recently, a Y-shaped graft was proposed for the connection of the inferior vena cava to the left and right pulmonary artery ${ }^{139}$. Theoretically, this graft is more energetically favorable and provides better distribution of hepatic blood flow between the left and right pulmonary artery, distributing "hepatic factors" that may prevent the formation of intrapulmonary collaterals more equally. Worse energetic performance and pulmonary flow distributions in comparison with ECC connections have been noticed in practice ${ }^{140,141}$.
Fontan completion without cardiopulmonary bypass, particularly with the ECC technique, is an attractive option. However, experience is still limited and reported rates of conduit replacement and outcomes following off-pump procedures differ across centers $^{142-145}$.

Less-invasive surgical approaches such as lateral thoracotomy have been described in this population ${ }^{146}$. Hybrid procedures, which combine transcatheter and surgical approaches, have been implemented in the initial management of HLHS ${ }^{147}$. Long-term outcomes are favorable, and some centers have adopted this hybrid approach as the standard for selected patient populations ${ }^{148}$.

\section{Remaining challenges}

A contemporary Fontan strategy uses either the ILT or the ECC modification. Two large meta-analyses have recently compared surgical strategies and found no differences in early or late mortality and Fontan takedown between ECC and ILT $^{33,149}$. Theoretical advantages of both techniques have been discussed extensively in the literature ${ }^{150,151}$. Further research should assess contemporary differences in outcomes between modifications and help guide the preferred procedure for future Fontan patients. This may include alternative concepts, like the Y-graft or combinations with external energy supply (pumps).

Remodeling of the SV, which is exposed to volume overload at birth and is volume-deprived following the TCPC procedure, is not very well understood. A better understanding of mechanisms of remodeling during these stages and the interaction of ventricular size and function with the Fontan baffle function, pulmonary circulation, atrial function, and VA interaction is required to find better means to preserve cardiac function. The search for new targets for drugs that may help to preserve cardiac and circulatory function continues.

Some controversy regarding the timing of TCPC surgery exists. Proponents of early TCPC argue that a prolonged period of volume overload leads to adverse cardiac remodeling and reduced cardiac function ${ }^{152}$. Others argue that the Fontan circulation inherently leads to complications and that surgery should be delayed to reduce the amount of time in Fontan physiology ${ }^{153}$. Other factors to be considered are the techniques used; ILT allows TCPC at lower body weight than ECC since small-sized conduits $(<18 \mathrm{~mm})$ need to be avoided ${ }^{152,154}$. Studies assessing the optimal timing of ECC procedures are currently being performed.

The effect of systemic to pulmonary venous and aortopulmonary collaterals on the Fontan circulation remains poorly understood. These collaterals could provide some benefit in patients with a suboptimal Fontan circuit. How these collaterals develop and why some patients seem more prone to this development remain to be determined. Increasing our understanding of the role of collaterals could help guide the selection of patients who will benefit from intervention. This requires 
well-designed (multicenter) studies. Several treatment modalities of PLE have been described in small series, including catheter-based strategies of both blood and lymphatic vessels and surgical re-implantation of the innominate vein into the common atrium ${ }^{155-159}$. More comprehensive analysis is needed to determine the efficacy and safety of these procedures.

Drug therapy has been shown to be able to decrease pulmonary vascular resistance in the short-term, making this a promising therapy for the Fontan patient. However, currently, no long-term benefit has been demonstrated. The role of drug therapy in the Fontan circulation needs to be studied more extensively.

These questions require answers to make better-informed decisions in the management of these challenging patients, who have some of the most severe kinds of CHD. We have an opportunity to help this growing patient population not just to survive but also to thrive and live full and satisfying lives.

\section{Conclusions}

The modern Fontan strategy has significantly transformed outcomes for patients with univentricular CHD. This has led to a large and growing population of Fontan patients surviving into adulthood. However, morbidity remains high and increases as this population ages and grows in proportion. Efforts to reduce morbidity and improve quality of life in these patients are ongoing. These efforts are focused on improving surgical techniques, developing novel diagnostic and therapeutic tools, and increasing our understanding of the highly abnormal Fontan physiology.

\section{Abbreviations}

APC, atriopulmonary connection; AV, atrioventricular; CHD, congenital heart disease; CMR, cardiac magnetic resonance (imaging); ECC, extracardiac conduit; GFR, glomerular filtration rate; HLHS, hypoplastic left heart syndrome; ILT, intra-atrial lateral tunnel; MRI, magnetic resonance imaging; NOAC, novel oral anticoagulant; PCPC, partial cavopulmonary connection; PLE, protein-losing enteropathy; SV, single ventricle; SVT, supraventricular tachycardia; TCPC, total cavopulmonary connection; VA, ventricular-arterial; VKA, vitamin K antagonist.

Competing interests

No competing interests were disclosed.

\section{Grant information}

The author(s) declared that no grants were involved in supporting this work.
1. Idorn L, Olsen M, Jensen AS, et al:: Univentricular hearts in Denmark 1977 to 2009: incidence and survival. Int J Cardiol. 2013; 167(4): 1311-6. PubMed Abstract | Publisher Full Text

2. Moons $\mathrm{P}$, Sluysmans $\mathrm{T}$, De Wolf $\mathrm{D}$, et al.: Congenital heart disease in 111225 births in Belgium: birth prevalence, treatment and survival in the 21st century. Acta Paediatr. 2009; 98(3): 472-7. PubMed Abstract | Publisher Full Tex

3. Schwedler G, Lindinger A, Lange PE, et al:: Frequency and spectrum of congenital heart defects among live births in Germany: a study of the Competence Network for Congenital Heart Defects. Clin Res Cardiol. 2011; 100(12): 1111-7. PubMed Abstract | Publisher Full Text

4. Khairy P, Poirier N, Mercier LA: Univentricular heart. Circulation. 2007; 115(6): $800-12$.

PubMed Abstract | Publisher Full Text

5. Coats L, O'Connor S, Wren C, et al:: The single-ventricle patient population: a current and future concern a population-based study in the North of England. Heart. 2014; 100(17): 1348-53.

PubMed Abstract | Publisher Full Text

6. Beghetti M: Pulmonary vasodilators in Fontan Patients. EUROGUCH 2017; Lausanne 2017.

Reference Source

7. van Velzen CL, Ket JCF, van de Ven PM, et al.: Systematic review and metaanalysis of the performance of second-trimester screening for prenatal detection of congenital heart defects. Int J Gynaecol Obstet. 2018; 140(2): 137-45.

PubMed Abstract | Publisher Full Text

8. Fontan F, Baudet E: Surgical repair of tricuspid atresia. Thorax. 1971; 26(3): 240-8.

PubMed Abstract | Publisher Full Text | Free Full Text

9. F Poh CL, Zannino D, Weintraub RG, et al:: Three decades later: The fate of the population of patients who underwent the Atriopulmonary Fontan procedure. Int J Cardiol. 2017; 231: 99-104.

PubMed Abstract | Publisher Full Text | F1000 Recommendation
10. de Leval MR, Kilner P, Gewillig M, et al.: Total cavopulmonary connection: a logical alternative to atriopulmonary connection for complex Fontan operations. Experimental studies and early clinical experience. J Thorac operations. Experimental studies and
Cardiovasc Surg. 1988; 96(5): 682-95. Cardiovasc Surg. 1
PubMed Abstract

11. Kerlo AEM, Delorme YT, Xu D, et al.: Experimental characterization of powered Fontan hemodynamics in an idealized total cavopulmonary connection model. Exp Fluids. 2013; 54: 1581 Publisher Full Text

12. Huang $L$, Dalziel KM, Schilling $C$, et al: Hospital costs and cost implications of co-morbid conditions for patients with single ventricle in the period through to Fontan completion. Int J Cardiol. 2017; 240: 178-82. PubMed Abstract | Publisher Full Text

13. Cedars A, Benjamin L, Vyhmeister R, et al: Contemporary Hospitalization Rate Among Adults With Complex Congenital Heart Disease. World J Pediatr Congenit Heart Surg. 2016; 7(3): 334-43. PubMed Abstract | Publisher Full Text

14. Tabtabai S, DeFaria Yeh D, Stefanescu A, et al: National Trends in Hospitalizations for Patients With Single-Ventricle Anatomy. Am J Cardiol. 2015; 116(5): 773-8

PubMed Abstract | Publisher Full Text

15. Collins RT 2nd, Fram RY, Tang X, et al:: Hospital utilization in adults with single ventricle congenital heart disease and cardiac arrhythmias. $J$ Cardiovasc Electrophysiol. 2014; 25(2): 179-86. PubMed Abstract | Publisher Full Text

16. Huang L, Schilling C, Dalziel KM, et al:: Hospital Inpatient Costs for Single Ventricle Patients Surviving the Fontan Procedure. Am J Cardiol. 2017; 120(3): $467-72$.

PubMed Abstract | Publisher Full Text

17. Gewillig M: The Fontan circulation. Heart. 2005; 91(6): 839-46. PubMed Abstract | Publisher Full Text | Free Full Text

18. Rychik J: The Relentless Effects of the Fontan Paradox. Semin Thorac Cardiovasc Surg Pediatr Card Surg Annu. 2016; 19(1): 37-43. PubMed Abstract | Publisher Full Text 
19. Fontan F, Kirklin JW, Fernandez G, et al.: Outcome after a "perfect" Fontan operation. Circulation. 1990; 81(5): 1520-36.

PubMed Abstract | Publisher Full Text

20. Gewillig M, Brown SC: The Fontan circulation after $\mathbf{4 5}$ years: update in physiology. Heart. 2016; 102(14): 1081-6.

PubMed Abstract | Publisher Full Text | Free Full Text

21. F Kverneland LS, Kramer P, Ovroutski S: Five decades of the Fontan operation: A systematic review of international reports on outcomes after univentricular palliation. Congenit Heart Dis. 2018; 13(2): 181-93. PubMed Abstract | Publisher Full Text | F1000 Recommendation

22. lyengar AJ, Winlaw DS, Galati JC, et al.: Trends in Fontan surgery and risk factors for early adverse outcomes after Fontan surgery: the Australia and New Zealand Fontan Registry experience. J Thorac Cardiovasc Surg. 2014; 148(2): 566-75.

PubMed Abstract | Publisher Full Text

23. d'Udekem Y, lyengar AJ, Galati JC, et al.: Redefining expectations of long-term survival after the Fontan procedure: twenty-five years of follow-up from the entire population of Australia and New Zealand. Circulation. 2014; 130(11 Supp 1): S32-8.

PubMed Abstract | Publisher Full Text

24. F Pundi KN, Johnson JN, Dearani JA, et al:: 40-Year Follow-Up After the Fontan Operation: Long-Term Outcomes of 1,052 Patients. J Am Coll Cardiol. 2015; 66(15): 1700-10.

PubMed Abstract | Publisher Full Text | F1000 Recommendation

25. F Alsaied T, Bokma JP, Engel ME, et al:: Factors associated with long-term mortality after Fontan procedures: a systematic review. Heart. 2017; 103(2): $104-10$.

PubMed Abstract | Publisher Full Text | F1000 Recommendation

26. Ohuchi $\mathrm{H}$, Yasuda K, Miyazaki A, et al.: Comparison of prognostic variables in children and adults with Fontan circulation. Int J Cardiol. 2014; 173(2): 277-83. PubMed Abstract | Publisher Full Text

27. F Fernandes SM, Alexander ME, Graham DA, et al:: Exercise testing identifies patients at increased risk for morbidity and mortality following Fontan surgery. Congenit Heart Dis. 2011; 6(4): 294-303.

PubMed Abstract | Publisher Full Text | F1000 Recommendation

28. Diller GP, Giardini A, Dimopoulos K, et al:: Predictors of morbidity and mortality in contemporary Fontan patients: results from a multicenter study including cardiopulmonary exercise testing in 321 patients. Eur Heart J. 2010; 31(24): 3073-83.

PubMed Abstract | Publisher Full Text

29. Assenza GE, Graham DA, Landzberg MJ, et al.: MELD-XI score and cardiac mortality or transplantation in patients after Fontan surgery. Heart. 2013; 99(7): $491-6$.

PubMed Abstract | Publisher Full Text

30. F Dimopoulos K, Diller GP, Koltsida E, et al:: Prevalence, predictors, and prognostic value of renal dysfunction in adults with congenital heart disease. Circulation. 2008; 117(18): 2320-8.

PubMed Abstract | Publisher Full Text | F1000 Recommendation

31. Nakano $\mathrm{T}$, Kado H, Tatewaki H, et al.: Results of extracardiac conduit total cavopulmonary connection in $\mathbf{5 0 0}$ patients. Eur J Cardiothorac Surg. 2015 48(6): 825-32; discussion 832

PubMed Abstract | Publisher Full Text

32. Giannakoulas G, Dimopoulos K, Yuksel S, et al.: Atrial tachyarrhythmias late after Fontan operation are related to increase in mortality and hospitalization. Int $J$ Cardiol. 2012; 157(2): 221-6.

PubMed Abstract | Publisher Full Text

33. $\mathrm{F}$ Lin $\mathrm{Z}, \mathrm{Ge} \mathrm{H}, \mathrm{Xue} J$, et al.: Comparison of extracardiac conduit and lateral tunnel for functional single-ventricle patients: A meta-analysis. Congenit Heart Dis. 2017; 12(6): 711-20.

PubMed Abstract | Publisher Full Text | F1000 Recommendation

34. Bossers SS, Duppen N, Kapusta L, et al:: Comprehensive rhythm evaluation in a large contemporary Fontan population. Eur J Cardiothorac Surg. 2015; 48(6): 833-40; discussion 840-1.

PubMed Abstract | Publisher Full Text

35. F Atz AM, Zak V, Mahony L, et al.: Longitudinal Outcomes of Patients With Single Ventricle After the Fontan Procedure. J Am Coll Cardiol. 2017; 69(22): 2735-44.

PubMed Abstract | Publisher Full Text | Free Full Text | F1000 Recommendation

36. Deal BJ, Jacobs ML: Management of the failing Fontan circulation. Heart. 2012; 98(14): 1098-104.

PubMed Abstract | Publisher Full Text | Free Full Text

37. Viswanathan S: Thromboembolism and anticoagulation after Fontan surgery. Ann Pediatr Cardiol. 2016; 9(3): 236-40.

PubMed Abstract | Publisher Full Text | Free Full Text

38. Egbe AC, Connolly HM, McLeod CJ, et al.: Thrombotic and Embolic Complications Associated With Atrial Arrhythmia After Fontan Operation: Role of Prophylactic Therapy. J Am Coll Cardiol. 2016; 68(12): 1312-9. PubMed Abstract | Publisher Full Text

39. Seipelt RG, Franke A, Vazquez-Jimenez JF, et al:: Thromboembolic complications after Fontan procedures: comparison of different therapeutic approaches. Ann Thorac Surg. 2002; 74(2): 556-62.

PubMed Abstract | Publisher Full Text

40. F Egbe AC, Connolly HM, Niaz T, et al:: Prevalence and outcome of thrombotic and embolic complications in adults after Fontan operation. $A m$ Heart J. 2017; 183: 10-7.

PubMed Abstract | Publisher Full Text | F1000 Recommendation

41. Balling $\mathrm{G}$, Vogt $\mathrm{M}, \mathrm{Kaemmerer} \mathrm{H}$, et al:: Intracardiac thrombus formation after the Fontan operation. J Thorac Cardiovasc Surg. 2000; 119(4 Pt 1): 745-52. PubMed Abstract | Publisher Full Text

42. $\mathrm{F}$ Khairy $\mathrm{P}$, Fernandes SM, Mayer JE, et al.: Long-term survival, modes of death, and predictors of mortality in patients with Fontan surgery. Circulation. 2008; 117(1): 85-92.

PubMed Abstract | Publisher Full Text | F1000 Recommendation

43. Ghaferi AA, Hutchins GM: Progression of liver pathology in patients undergoing the Fontan procedure: Chronic passive congestion, cardiac cirrhosis, hepatic adenoma, and hepatocellular carcinoma. J Thorac Cardiovasc Surg. 2005; 129(6): 1348-52.

PubMed Abstract | Publisher Full Text

44. Greenway SC, Crossland DS, Hudson M, et al:: Fontan-associated liver disease: Implications for heart transplantation. J Heart Lung Transplant. 2016; 35(1): $26-33$.

PubMed Abstract | Publisher Full Text

45. Hilscher MB, Johnson JN, Cetta F, et al:: Surveillance for liver complications after the Fontan procedure. Congenit Heart Dis. 2017; 12(2): 124-32. PubMed Abstract | Publisher Full Text

46. Daniels CJ, Bradley EA, Landzberg MJ, et al:: Fontan-Associated Liver Disease: Proceedings from the American College of Cardiology Stakeholders Meeting, October 1 to 2, 2015, Washington DC. J Am Coll Cardiol. 2017; 70(25): 3173-94. PubMed Abstract | Publisher Full Text

47. Johnson JN, Driscoll DJ, O'Leary PW: Protein-losing enteropathy and the Fontan operation. Nutr Clin Pract. 2012; 27(3): 375-84.

PubMed Abstract | Publisher Full Text

48. Schwartz I, McCracken CE, Petit CJ, et al.: Late outcomes after the Fontan procedure in patients with single ventricle: a meta-analysis. Heart. 2018; pii heartjnl-2017-312807.

PubMed Abstract | Publisher Full Text

49. Atz AM, Zak V, Mahony L, et al.: Survival data and predictors of functional outcome an average of 15 years after the Fontan procedure: the pediatric heart network Fontan cohort. Congenit Heart Dis. 2015; 10(1): E30-42. PubMed Abstract | Publisher Full Text | Free Full Text

50. Caruthers RL, Kempa M, Loo A, et al.: Demographic characteristics and estimated prevalence of Fontan-associated plastic bronchitis. Pediatr Cardiol. 2013; 34(2): 256-61.

PubMed Abstract | Publisher Full Text | Free Full Text

51. F Lee D, Levin A, Kiess M, et al.: Chronic kidney damage in the adult Fontan population. Int J Cardiol. 2018; 257: 62-6. PubMed Abstract | Publisher Full Text | F1000 Recommendation

52. F Opotowsky AR, Baraona FR, Mc Causland FR, et al:: Estimated glomerular filtration rate and urine biomarkers in patients with single-ventricle Fontan circulation. Heart. 2017; 103(6): 434-42. PubMed Abstract | Publisher Full Text | Free Full Text | F1000 Recommendation

53. F Singh S, Kumar R, Roy B, et al:: Regional brain gray matter changes in adolescents with single ventricle heart disease. Neurosci Lett. 2018; 665: 156-62.

156-62.

54. F Pike NA, Roy B, Gupta R, et al.: Brain abnormalities in cognition, anxiety, and depression regulatory regions in adolescents with single ventricle heart disease. J Neurosci Res. 2018; 96(6): 1104-18.

PublMed Abstract | Publisher Full Text | F1000 Recommendation

55. F Muneuchi J, Nagatomo Y, Okada S, et al:: Increased Pituitary Volumes in Children after Fontan Operation: Congestion in the Other Portal Circulation. $J$ Pediatr. 2018; 193: 249-51.

PubMed Abstract | Publisher Full Text | F1000 Recommendation

56. Ono $\mathrm{M}$, Boethig $\mathrm{D}$, Goerler $\mathrm{H}$, et al:: Clinical outcome of patients $\mathbf{2 0}$ years after Fontan operation--effect of fenestration on late morbidity. Eur J Cardiothorac Surg. 2006; 30(6): 923-9. PubMed Abstract | Publisher Full Text

57. Hannan RL, Zabinsky JA, Salvaggio JL, et al.: The Fontan operation: the pursuit of associated lesions and cumulative trauma. Pediatr Cardiol. 2011; 32(6): 778-84.

PubMed Abstract | Publisher Full Text | Free Full Text

58. Palumbo T, Sluysmans T, Rubay JE, et al:: Long-term outcome and anaesthetic management for non-cardiac surgery after Fontan palliation: a single-centre retrospective analysis. Cardiol Young. 2015; 25(6): 1148-54. PubMed Abstract | Publisher Full Text

59. Downing TE, Allen KY, Goldberg DJ, et al:: Surgical and Catheter-Based Reinterventions Are Common in Long-Term Survivors of the Fontan Operation. Circ Cardiovasc Interv. 2017; 10(9): pii: e004924. PubMed Abstract | Publisher Full Text

60. $\mathrm{F}$ Honjo $\mathrm{O}$, Atlin $\mathrm{CR}$, Mertens $\mathrm{L}$, et al:: Atrioventricular valve repair in patients 
with functional single-ventricle physiology: impact of ventricular and valve function and morphology on survival and reintervention. J Thorac Cardiovasc Surg. 2011; 142(2): 326-35.e2.

PubMed Abstract | Publisher Full Text | F1000 Recommendation

61. Mavroudis C, Deal BJ: Fontan Conversion: Literature Review and Lessons Learned Over 20 Years. World J Pediatr Congenit Heart Surg. 2016; 7(2): 192-8. PubMed Abstract | Publisher Full Text

62. Warnes CA, Williams RG, Bashore TM, et al.: ACC/AHA 2008 Guidelines for the Management of Adults with Congenital Heart Disease: Executive Summary: a report of the American College of Cardiology/American Heart Association Task Force on Practice Guidelines (writing committee to develop guidelines for the management of adults with congenital heart disease). Circulation. 2008; 118(23): 2395-451.

PubMed Abstract | Publisher Full Text

63. Honjo $\mathrm{O}$, Mertens $\mathrm{L}$, van Arsdell GS: Atrioventricular valve repair in patients with single-ventricle physiology: mechanisms, techniques of repair, and clinical outcomes. Semin Thorac Cardiovasc Surg Pediatr Card Surg Annu. 2011; 14(1): $75-84$.

PubMed Abstract | Publisher Full Text

64. Bridges ND, Lock JE Castaneda AR: Baffle fenestration with subsequen transcatheter closure. Modification of the Fontan operation for patients at increased risk. Circulation. 1990; 82(5): 1681-9. PubMed Abstract | Publisher Full Text

65. Kreutzer J, Graziano JN, Stapleton G, et al:: Late catheter interventions in hypoplastic left heart syndrome. Cardiol Young. 2011; 21Suppl 2: 65-76. PubMed Abstract | Publisher Full Tex

66. Poterucha JT, Johnson JN, Taggart NW, et al:: Embolization of Veno-venous Collaterals after the Fontan Operation Is Associated with Decreased Survival. Congenit Heart Dis. 2015; 10(5): E230-6.

PubMed Abstract | Publisher Full Tex

67. Schmitt B, Steendijk P, Ovroutski S, et al:: Pulmonary vascular resistance, collateral flow, and ventricular function in patients with a Fontan circulation at rest and during dobutamine stress. Circ Cardiovasc Imaging. 2010; 3(5): 623-31. PubMed Abstract | Publisher Full Text

68. Odenwald T, Quail MA, Giardini A, et al:: Systemic to pulmonary collateral blood flow influences early outcomes following the total cavopulmonary connection. Heart. 2012; 98(12): 934-40.

PubMed Abstract | Publisher Full Tex

69. de Groot NM, Lukac P, Blom NA, et al.: Long-term outcome of ablative therapy of postoperative supraventricular tachycardias in patients with univentricula heart: a European multicenter study. Circ Arrhythm Electrophysiol. 2009; 2(3): 242-8.

PubMed Abstract | Publisher Full Text

70. Yap S, Harris L, Silversides CK, et al:: Outcome of intra-atrial re-entran tachycardia catheter ablation in adults with congenital heart disease: negative impact of age and complex atrial surgery. J Am Coll Cardiol. 2010; 56(19): 1589-96.

PubMed Abstract | Publisher Full Text

71. Wilson TG, Shi WY, Iyengar AJ, et al.: Twenty-Five Year Outcomes of the Latera Tunnel Fontan Procedure. Semin Thorac Cardiovasc Surg. 2017; 29(3): 347-353. PubMed Abstract | Publisher Full Tex

72. Pihkala JI, Järvelä M, Boldt $\mathrm{T}$, et al.: Fate of fenestration in children treated with fontan operation. Catheter Cardiovasc Interv. 2016; 87(6): E233-9. PubMed Abstract | Publisher Full Text

73. Dancea A, Justino H, Martucci G: Catheter intervention for congenital heart disease at risk of circulatory failure. Can J Cardiol. 2013; 29(7): 786-795. PubMed Abstract | Publisher Full Text

74. Uzark K, Zak V, Shrader P, et al:: Assessment of Quality of Life in Young Patients with Single Ventricle after the Fontan Operation. J Pediatr. 2016; 170: 166-72e1.

PubMed Abstract | Publisher Full Text | Free Full Text

75. F Smaś-Suska M, Dłużniewska N, Weryński P, et al.: What determines the quality of life of adult patients after Fontan procedure? Cardiol J. 2018; 25(1): 72-80. PubMed Abstract | Publisher Full Text | F1000 Recommendation

76. Idorn L, Jensen AS, Juul K, et al: Quality of life and cognitive function in Fontan patients, a population-based study. Int J Cardiol. 2013; 168(4): 3230-5. PubMed Abstract | Publisher Full Text

77. F Vahsen N, Bröder A, Hraska V, et al.: Neurodevelopmental Outcome in Children With Single Ventricle After Total Cavopulmonary Connection. Klin Padiatr. 2018; 230(1): 24-30.

PubMed Abstract | Publisher Full Text | F1000 Recommendation

78. Kukreja M, Bryant AS, Cleveland DC, et al.: Health-Related Quality of Life in Adult Survivors After the Fontan Operation. Semin Thorac Cardiovasc Surg. 2015; 27(3): 299-306.

PubMed Abstract | Publisher Full Tex

79. Dulfer K, Bossers SS, Utens EM, et al.: Does functional health status predict health-related quality of life in children after Fontan operation? Cardiol Young 2016; 26(3): 459-68.

PubMed Abstract | Publisher Full Text

80. Bossers SS, Helbing WA, Duppen N, et al:: Exercise capacity in children after total cavopulmonary connection: lateral tunnel versus extracardiac conduit technique. J Thorac Cardiovasc Surg. 2014; 148(4): 1490-7.

PubMed Abstract | Publisher Full Text

81. Giardini A, Hager A, Pace Napoleone C, et al.: Natural history of exercise capacity after the Fontan operation: a longitudinal study. Ann Thorac Surg. 2008; 85(3): 818-21.

PubMed Abstract | Publisher Full Text

82. F Egbe AC, Driscoll DJ, Khan AR, et al: Cardiopulmonary exercise test in adults with prior Fontan operation: The prognostic value of serial testing. Int $J$ Cardiol. 2017; 235: 6-10.

PubMed Abstract | Publisher Full Text | F1000 Recommendation

83. F Cordina R, Du Plessis K, Tran D, et al.: Super-Fontan: Is it possible? J Thorac Cardiovasc Surg. 2018; 155(3): 1192-4. PubMed Abstract | Publisher Full Text | F1000 Recommendation

84. Dulfer K, Duppen N, Kuipers IM, et al:: Aerobic exercise influences quality of life of children and youngsters with congenital heart disease: a randomized controlled trial. J Adolesc Health. 2014; 55(1): 65-72. PubMed Abstract | Publisher Full Text

85. McCrindle BW, Williams RV, Mital S, et al:: Physical activity levels in children and adolescents are reduced after the Fontan procedure, independent of exercise capacity, and are associated with lower perceived general health. Arch Dis Child. 2007; 92(6): 509-14.

PubMed Abstract | Publisher Full Text | Free Full Text

86. Duppen N, Etnel JR, Spaans L, et al:: Does exercise training improve cardiopulmonary fitness and daily physical activity in children and young adults with corrected tetralogy of Fallot or Fontan circulation? A randomized controlled trial. Am Heart J. 2015; 170(3): 606-14.

PubMed Abstract | Publisher Full Text

87. Takken T, Hulzebos HJ, Blank AC, et al:: Exercise prescription for patients with a Fontan circulation: current evidence and future directions. Neth Heart $J$. 2007; 15(4): 142-7.

PubMed Abstract | Publisher Full Text | Free Full Text

88. Brassard $\mathrm{P}$, Bédard $\mathrm{E}$, Jobin J, et al.: Exercise capacity and impact of exercise training in patients after a Fontan procedure: a review. Can J Cardiol. 2006; 22(6): 489-95.

PubMed Abstract | Publisher Full Text | Free Full Text

89. F Hedlund ER, Lundell B, Söderström L, et al.: Can endurance training improve physical capacity and quality of life in young Fontan patients? Cardiol Young. 2018; 28(3): 438-46.

PubMed Abstract | Publisher Full Text | F1000 Recommendation

90. Cordina RL, O'Meagher S, Karmali A, et al:: Resistance training improves cardiac output, exercise capacity and tolerance to positive airway pressure in Fontan physiology. Int J Cardiol. 2013; 168(2): 780-8.

PubMed Abstract | Publisher Full Text

91. F Laohachai K, Winlaw D, Selvadurai $\mathrm{H}$, et al.: Inspiratory Muscle Training s Associated With Improved Inspiratory Muscle Strength, Resting Cardiac Output, and the Ventilatory Efficiency of Exercise in Patients With a Fontan Circulation. J Am Heart Assoc. 2017; 6(8): pii: e005750. PubMed Abstract | Publisher Full Text | Free Full Text | F1000 Recommendation

92. Khairy $\mathrm{P}$, Ouyang DW, Fernandes SM, et al.: Pregnancy outcomes in women with congenital heart disease. Circulation. 2006; 113(4): 517-24. PubMed Abstract | Publisher Full Text

93. Mair DD, Puga FJ, Danielson GK: Late functional status of survivors of the Fontan procedure performed during the 1970s. Circulation. 1992; 86(5 Suppl): |106-9.

PubMed Abstract

94. Pike NA, Evangelista LS, Doering LV, et al:: Clinical profile of the adolescent/ adult Fontan survivor. Congenit Heart Dis. 2011; 6(1): 9-17. PubMed Abstract | Publisher Full Text | Free Full Text

95. F Mohammad Nijres B, Murphy JJ, Diab K, et al.: Routine Cardiac Catheterization Prior to Fontan Operation: Is It a Necessity? Pediatr Cardiol. 2018; 39(4): 818-23.

PubMed Abstract | Publisher Full Text | F1000 Recommendation

96. Ro PS, Rychik J, Cohen MS, et al:: Diagnostic assessment before Fontan operation in patients with bidirectional cavopulmonary anastomosis: are noninvasive methods sufficient? J Am Coll Cardiol. 2004; 44(1): 184-7. PubMed Abstract | Publisher Full Text

97. Fogel MA, Pawlowski TW, Whitehead KK, et al.: Cardiac magnetic resonance and the need for routine cardiac catheterization in single ventricle patients prior to Fontan: a comparison of 3 groups: pre-Fontan CMR versus cath evaluation. $J$ Am Coll Cardiol. 2012; 60(12): 1094-102. PubMed Abstract | Publisher Full Text

98. Valsangiacomo Buechel ER, Grosse-Wortmann L, Fratz S, et al.: Indications for cardiovascular magnetic resonance in children with congenital and acquired heart disease: an expert consensus paper of the Imaging Working Group of the AEPC and the Cardiovascular Magnetic Resonance Section of the EACVI. Eur Heart J Cardiovasc Imaging. 2015; 16(3): 281-97. PubMed Abstract | Publisher Full Text

99. Glatz AC, Rome JJ, Small AJ, et al:: Systemic-to-pulmonary collateral flow, as measured by cardiac magnetic resonance imaging, is associated with acute post-Fontan clinical outcomes. Circ Cardiovasc Imaging. 2012; 5(2): 218-25. PubMed Abstract | Publisher Full Text | Free Full Text

100. Grosse-Wortmann L, Drolet C, Dragulescu A, et al:: Aortopulmonary collateral flow volume affects early postoperative outcome after Fontan completion: a multimodality study. J Thorac Cardiovasc Surg. 2012; 144(6): 1329-36. PubMed Abstract | Publisher Full Text

101. F Lawley CM, Broadhouse KM, Callaghan FM, et al.: 4D flow magnetic 
resonance imaging: role in pediatric congenital heart disease. Asian Cardiovasc Thorac Ann. 2018; 26(1): 28-37.

PubMed Abstract | Publisher Full Text | F1000 Recommendation

102. Bächler $\mathrm{P}$, Valverde I, Pinochet $\mathrm{N}$, et al.: Caval blood flow distribution in patients with Fontan circulation: quantification by using particle traces from 4D flow MR imaging. Radiology. 2013; 267(1): 67-75. PubMed Abstract | Publisher Full Text

103. Rathod RH, Prakash A, Kim YY, et al.: Cardiac magnetic resonance parameters predict transplantation-free survival in patients with fontan circulation. Circ Cardiovasc Imaging. 2014; 7(3): 502-9.

PubMed Abstract | Publisher Full Text | Free Full Text

104. Ghelani SJ, Harrild DM, Gauvreau K, et al:: Comparison Between Echocardiography and Cardiac Magnetic Resonance Imaging in Predicting Transplant-Free Survival After the Fontan Operation. Am J Cardiol. 2015; 116(7): 1132-8. PubMed Abstract | Publisher Full Text

105. F Whitehead KK, Pekkan K, Kitajima HD, et al:: Nonlinear power loss during exercise in single-ventricle patients after the Fontan: insights from computational fluid dynamics. Circulation. 2007; 116(11 Suppl): I165-71. PubMed Abstract | Publisher Full Text | F1000 Recommendation

106. F Park PW, Atz AM, Taylor CL, et al:: Speckle-Tracking Echocardiography Improves Pre-operative Risk Stratification Before the Total Cavopulmonary Connection. J Am Soc Echocardiogr. 2017; 30(5): 478-84. PubMed Abstract | Publisher Full Text | Free Full Text | F1000 Recommendation

107. F Saiki H, Eidem BW, Ohtani T, et al:: Ventricular-Arterial Function and Coupling in the Adult Fontan Circulation. J Am Heart Assoc. 2016; 5(9): pii: e003887.

PubMed Abstract | Publisher Full Text | Free Full Text | F1000 Recommendation

108. Dori Y, Keller MS, Fogel MA, et al.: MRI of lymphatic abnormalities after functional single-ventricle palliation surgery. AJR Am J Roentgenol. 2014; 203(2): 426-31.

PubMed Abstract | Publisher Full Text

109. Dori Y, Keller MS, Rome JJ, et al:: Percutaneous Lymphatic Embolization of Abnormal Pulmonary Lymphatic Flow as Treatment of Plastic Bronchitis in Patients With Congenital Heart Disease. Circulation. 2016; 133(12): 1160-70. PubMed Abstract | Publisher Full Text

110. F Itkin M, Piccoli DA, Nadolski G, et al:: Protein-Losing Enteropathy in Patients With Congenital Heart Disease. J Am Coll Cardiol. 2017; 69(24): 2929-37. PubMed Abstract | Publisher Full Text | F1000 Recommendation

111. Cromme-Dijkhuis $\mathrm{AH}$, Hess J, Hählen $\mathrm{K}$, et al:: Specific sequelae after Fontan operation at mid- and long-term follow-up. Arrhythmia, liver dysfunction, and coagulation disorders. J Thorac Cardiovasc Surg. 1993; 106: 1126-32. PubMed Abstract

112. Alsaied $\mathrm{T}$, Alsidawi $\mathrm{S}$, Allen CC, et al:: Strategies for thromboprophylaxis in Fontan circulation: a meta-analysis. Heart. 2015; 101(21): 1731-7. PubMed Abstract | Publisher Full Text

113. F McCrindle BW, Manlhiot C, Cochrane A, et al:: Factors associated with thrombotic complications after the Fontan procedure: a secondary analysis of a multicenter, randomized trial of primary thromboprophylaxis for 2 years after the Fontan procedure. J Am Coll Cardiol. 2013; 61(3): 346-53. PubMed Abstract | Publisher Full Text | F1000 Recommendation

114. F Yang H, Bouma BJ, Mulder BJM: Is Initiating NOACs for Atrial Arrhythmias Safe in Adults with Congenital Heart Disease? Cardiovasc Drugs Ther. 2017; 31(4): 413-7.

PubMed Abstract | Publisher Full Text | Free Full Text | F1000 Recommendation

115. Wilson TG, lyengar AJ, Winlaw DS, et al.: Use of ACE inhibitors in Fontan: Rational or irrational? Int J Cardiol. 2016; 210: 95-9. PubMed Abstract | Publisher Full Text

116. Wilson TG, lyengar AJ, d'Udekem Y: The Use and Misuse of ACE Inhibitors in Patients with Single Ventricle Physiology. Heart Lung Circ. 2016; 25(3): 229-36. PubMed Abstract | Publisher Full Text

117. Morchi GS, Ivy DD, Duster MC et al: Sildenafil Increases Systemic Saturation and Reduces Pulmonary Artery Pressure in Patients with Failing Fontan Physiology. Congenit Heart Dis. 2009; 4(2): 107-11. PubMed Abstract | Publisher Full Text | Free Full Text

118. Giordano R, Palma G, Poli V, et al.: First experience with sildenafil after Fontan operation: short-term outcomes. J Cardiovasc Med (Hagerstown). 2015; 16(8): $552-5$.

PubMed Abstract | Publisher Full Text

119. Oldenburger NJ, Mank A, Etnel J, et al:: Drug therapy in the prevention of failure of the Fontan circulation: a systematic review. Cardiol Young. 2016; 26(5): 842-50. PubMed Abstract | Publisher Full Text

120. Mori H, Park IS, Yamagishi H, et al:: Sildenafil reduces pulmonary vascular resistance in single ventricular physiology. Int J Cardiol. 2016; 221: 122-7. PubMed Abstract | Publisher Full Text

121. Hebert A, Mikkelsen UR, Thilen U, et al.: Bosentan improves exercise capacity in adolescents and adults after Fontan operation: the TEMPO (Treatment With Endothelin Receptor Antagonist in Fontan Patients, a Randomized, PlaceboControlled, Double-Blind Study Measuring Peak Oxygen Consumption) study. Circulation. 2014; 130(23): 2021-30.

PubMed Abstract | Publisher Full Text

122. Shang $X$, Lu R, Zhang $X$, et al.: Efficacy of Bosentan in patients after Fontan procedures: a double-blind, randomized controlled trial. J Huazhong Univ Sci Technol Med Sci. 2016; 36(4): 534-40. PubMed Abstract | Publisher Full Text

123. Ovaert $C$, Thijs $D$, Dewolf $D$, et al.: The effect of bosentan in patients with a failing Fontan circulation. Cardiol Young. 2009; 19(4): 331-9. PubMed Abstract | Publisher Full Text

124. Schuuring MJ, Vis JC, van Dijk AP, et al.: Impact of bosentan on exercise capacity in adults after the Fontan procedure: a randomized controlled trial. Eur J Heart Fail. 2013; 15(6): 690-8. PubMed Abstract | Publisher Full Text

125. Park I: Efficacy of pulmonary vasodilator therapy in patients with functionally single ventricle. Int Heart J. 2015; 56Suppl: S26-30. PubMed Abstract | Publisher Full Text

126. F Agnoletti G, Gala S, Ferroni F, et al.: Endothelin inhibitors lower pulmonary vascular resistance and improve functional capacity in patients with Fontan circulation. J Thorac Cardiovasc Surg. 2017; 153(6): 1468-75. PubMed Abstract | Publisher Full Text | F1000 Recommendation

127. Chopski SG, Moskowitz WB, Stevens RM, et al.: Mechanical Circulatory Support Devices for Pediatric Patients With Congenital Heart Disease. Artif Organs. 2017; 41(1): E1-E14.

PubMed Abstract | Publisher Full Text

128. Carlo WF, Villa CR, Lal AK, et al.: Ventricular assist device use in single ventricle congenital heart disease. Pediatr Transplant. 2017; 21(7): e13031. PubMed Abstract | Publisher Full Text

129. F Blume ED, VanderPluym C, Lorts A, et al:: Second annual Pediatric Interagency Registry for Mechanical Circulatory Support (Pedimacs) report: Pre-implant characteristics and outcomes. J Heart Lung Transplant. 2018; 37(1): 38-45. PubMed Abstract | Publisher Full Text | F1000 Recommendation

130. F Lorts A, Eghtesady P, Mehegan M, et al:: Outcomes of children supported with devices labeled as "temporary" or short term: A report from the Pediatric Interagency Registry for Mechanical Circulatory Support. $J$ Heart Lung Transplant. 2018; 37(1): 54-60.

PubMed Abstract | Publisher Full Text | F1000 Recommendation

131. Rossano JW, Goldberg DJ, Fuller S, et al:: Successful use of the total artificial heart in the failing Fontan circulation. Ann Thorac Surg. 2014; 97(4): 1438-40. PubMed Abstract | Publisher Full Text

132. Rossano JW, Woods RK, Berger S, et al: Mechanical support as failure intervention in patients with cavopulmonary shunts (MFICS): rationale and aims of a new registry of mechanical circulatory support in single ventricle patients. Congenit Heart Dis. 2013; 8(3): 182-6.

PubMled Abstract | Publisher Full Tex

133. F Poh CL, Chiletti R, Zannino D, et al.: Ventricular assist device support in patients with single ventricles: the Melbourne experience. Interact Cardiovasc Thorac Surg. 2017; 25(2): 310-6.

PubMed Abstract | Publisher Full Text | F1000 Recommendation

134. Horne D, Conway J, Rebeyka IM, et al:: Mechanical circulatory support in univentricular hearts: current management. Semin Thorac Cardiovasc Surg Pediatr Card Surg Annu. 2015; 18(1): 17-24.

PubMed Abstract | Publisher Full Text

135. Weinstein S, Bello R, Pizarro $C$, et al:: The use of the Berlin Heart EXCOR in patients with functional single ventricle. J Thorac Cardiovasc Surg. 2014; 147(2): 697-704; discussion 70-45.

PubMed Abstract | Publisher Full Text

136. Mauchley DC, Mitchell MB: Transplantation in the Fontan patient. Semin Thorac Cardiovasc Surg Pediatr Card Surg Annu. 2015; 18(1): 7-16. PubMed Abstract | Publisher Full Text

137. Rossano JW, Shaddy RE: Heart transplant after the Fontan operation. Cardiol Young. 2013; 23(6): 841-6. PubMed Abstract | Publisher Full Text

138. Kanter KR: Heart Transplantation in Children after a Fontan Procedure: Better than People Think. Semin Thorac Cardiovasc Surg Pediatr Card Surg Annu. 2016; 19(1): 44-9. PubMed Abstract | Publisher Full Text

139. Martin MH, Feinstein JA, Chan FP, et al.: Technical feasibility and intermediate outcomes of using a handcrafted, area-preserving, bifurcated Y-graft modification of the Fontan procedure. J Thorac Cardiovasc Surg. 2015; 149(1): 239-45.e1.

PubMed Abstract | Publisher Full Text

140. F Trusty PM, Wei Z, Tree M, et al.: Local Hemodynamic Differences Between Commercially Available Y-Grafts and Traditional Fontan Baffles Under Simulated Exercise Conditions: Implications for Exercise Tolerance. Cardiovasc Eng Technol. 2017; 8(3): 390-9. PubMed Abstract | Publisher Full Text | F1000 Recommendation

141. Trusty PM, Restrepo M, Kanter KR, et al:: A pulsatile hemodynamic evaluation of the commercially available bifurcated Y-graft Fontan modification and comparison with the lateral tunnel and extracardiac conduits. $J$ Thorac Cardiovasc Surg. 2016; 151(6): 1529-36. PubMed Abstract | Publisher Full Text

142. Mainwaring RD, Reddy VM, Hanley FL: Completion of the Three-Stage Fontan Pathway Without Cardiopulmonary Bypass. World J Pediatr Congenit Heart Surg. 2014; 5(3): 427-33

PubMed Abstract | Publisher Full Tex 
143. LaPar DJ, Mery CM, Peeler BB, et al.: Short and long-term outcomes for bidirectional glenn procedure performed with and without cardiopulmonary bypass. Ann Thorac Surg. 2012; 94(1): 164-70; discussion 170-1. PubMed Abstract | Publisher Full Text

144. Ovroutski S, Sohn C, Miera O, et al:: Improved early postoperative outcome for extracardiac Fontan operation without cardiopulmonary bypass: a singlecentre experience. Eur J Cardiothorac Surg. 2013; 43(5): 952-7. PubMed Abstract | Publisher Full Text

145. Talwar S, Muthukkumaran S, Choudhary SK, et al:: A complete extracorporeal circulation-free approach to patients with functionally univentricular hearts provides superior early outcomes. World J Pediatr Congenit Heart Surg. 2014; 5(1): 54-9.

PubMed Abstract | Publisher Full Text

146. F Sett SS, Lafaro RJ: Extracardiac Fontan Operation Through a Right Thoracotomy. Ann Thorac Surg. 2017; 104(2): e147-e149. PubMed Abstract | Publisher Full Text | F1000 Recommendation

147. Akintuerk $\mathrm{H}$, Michel-Behnke I, Valeske $\mathrm{K}$, et al.: Stenting of the arterial duct and banding of the pulmonary arteries: basis for combined Norwood stage I and I repair in hypoplastic left heart. Circulation. 2002; 105(9): 1099-103. PubMed Abstract | Publisher Full Text

148. Schranz D, Bauer A, Reich B, et al.: Fifteen-year single center experience with the "Giessen Hybrid" approach for hypoplastic left heart and variants: curren strategies and outcomes. Pediatr Cardiol. 2015; 36(2): 365-73. PubMed Abstract | Publisher Full Text | Free Full Text

149. F Zheng J, Li Z, Li Q, et al.: Meta-analysis of Fontan procedure: Extracardiac conduit vs. intracardiac lateral tunnel. Herz. 2018; 43(3): 238-45. PubMed Abstract | Publisher Full Text | F1000 Recommendation

150. Kogon B: Is the extracardiac conduit the preferred Fontan approach for patients with univentricular hearts? The extracardiac conduit is the preferred Fontan approach for patients with univentricular hearts. Circulation. 2012; 126(21): 2511-5; discussion 2515. PubMed Abstract | Publisher Full Text

151. Khairy $P$, Poirier N: Is the extracardiac conduit the preferred Fontan approach for patients with univentricular hearts? The extracardiac conduit is not the preferred Fontan approach for patients with univentricular hearts. Circulation. 2012; 126(21): 2516-25; discussion 2525

PubMed Abstract | Publisher Full Text

152. Pace Napoleone C, Oppido G, Angeli E, et al:: Results of the modified Fontan procedure are not related to age at operation. Eur J Cardiothorac Surg. 2010; 37(3): $645-50$

PubMed Abstract | Publisher Full Text

153. d'Udekem Y, Xu MY, Konstantinov IE: The optimal age at Fontan procedure and the 'ticking clock' theory: do we have an answer? Eur J Cardiothorac Surg. 2011; 39(1): 144; author reply 144-5.

PubMed Abstract | Publisher Full Text

154. Dabal RJ, Kirklin JK, Kukreja M, et al:: The modern Fontan operation shows no increase in mortality out to 20 years: a new paradigm. J Thorac Cardiovasc Surg. 2014; 148(6): 2517-23.e1.

PubMed Abstract | Publisher Full Text

155. F Devanagondi R, Suntharos P, Boyle GJ, et al:: Protein Losing Enteropathy After Cardiac Transplantation Successfully Treated by Stent Implantation World J Pediatr Congenit Heart Surg. 2017; 8(6): 754-757. PubMed Abstract | Publisher Full Text | F1000 Recommendation

156. Brizard CP, Lane GK, Alex G, et al:: Original Surgical Procedure for the Treatment of Protein-Losing Enteropathy in Fontan Patients: Report of Two Midterm Successes. Circulation. 2016; 134(8): 625-7. PubMed Abstract | Publisher Full Text

157. Kreutzer C, Kreutzer G: The Lymphatic System: The Achilles Heel of the FontanKreutzer Circulation. World J Pediatr Congenit Heart Surg. 2017; 8(5): 613-623. PubMed Abstract | Publisher Full Text

158. Menon S, Chennapragada M, Ugaki S, et al.: The Lymphatic Circulation in Adaptations to the Fontan Circulation. Pediatr Cardiol. 2017; 38(5): 886-892. PubMed Abstract | Publisher Full Text

159. Hraška V: Decompression of thoracic duct: new approach for the treatment of failing Fontan. Ann Thorac Surg. 2013; 96(2): 709-11. PubMed Abstract | Publisher Full Text 


\section{Open Peer Review}

\section{Current Peer Review Status:}

\section{Editorial Note on the Review Process}

Faculty Reviews are review articles written by the prestigious Members of Faculty Opinions. The articles are commissioned and peer reviewed before publication to ensure that the final, published version is comprehensive and accessible. The reviewers who approved the final version are listed with their names and affiliations.

\section{The reviewers who approved this article are:}

\section{Version 1}

\section{Amy Throckmorton}

BioCirc Research Laboratory, School of Biomedical Engineering, Science and Health Systems, Drexel University, Philadelphia, Pennsylvania, USA

Competing Interests: No competing interests were disclosed.

\section{Gruschen R. Veldtman}

Adolescent and Adult Congenital Heart Disease Program, Cincinnati Children's Hospital Medical Centre, Cincinnati, Ohio, USA

Competing Interests: No competing interests were disclosed.

The benefits of publishing with F1000Research:

- Your article is published within days, with no editorial bias

- You can publish traditional articles, null/negative results, case reports, data notes and more

- The peer review process is transparent and collaborative

- Your article is indexed in PubMed after passing peer review

- Dedicated customer support at every stage

For pre-submission enquiries, contact research@f1000.com

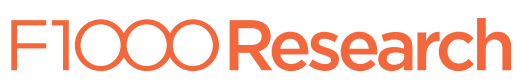

